Proc. Estonian Acad. Sci. Geol., 2004, 53, 4, 233-245

\title{
Diversity of late Ordovician rugose corals in Baltoscandia: role of environmental changes and comparison with other areas
}

\begin{abstract}
Dimitri Kaljo
Institute of Geology at Tallinn University of Technology, Estonia pst. 7, 10143 Tallinn, Estonia; kaljo@gi.ee

Received 13 October 2004, in revised form 8 November 2004

Abstract. Regional biodiversity curves are controlled environmentally and reveal details that can be correlated with stable isotope data, sea level curves, etc. This paper uses such ties for better understanding of the environmental background of certain palaeobiological events. The first appearance of rugose corals in the shelf seas of Baltica in the Middle Caradoc seems to be linked to the warming of sea water and climate due to the drift of the continent closer to the equator. The same factor also favoured a further biodiversity rise in which both biology and ecology should be considered. The general diversity rise was slowed down by repeated coolings in the late Caradoc and early Ashgill and caused a diversity low within the early Ashgill. Along with a favourable temperature regime, changes in oceanic circulation, nutrient flow, and availability of suitable habitats were of great importance. The Hirnantian glaciation, accompanied by a pronounced sea level fall, brought about favourable conditions for coral evolution on many subequatorial cratonic shelves, which helped corals to survive the severe conditions of the end-Ordovician glacial time. The Baltoscandian rugose coral assemblage is the most diverse by comparison with those of Australasia and Laurentia thanks to the abundance of old lambelasmatids living in relatively cooler and deeper habitats.
\end{abstract}

Key words: rugose corals, biodiversity, carbon isotopes, Ordovician, Baltoscandia.

\section{INTRODUCTION}

The International Geoscience Programme (IGCP) Project 410 was completed successfully in the spring of 2004. The results were summarized in a voluminous book, The Great Ordovician Biodiversification Event (Webby et al. 2004a). As documented in the book the Ordovician showed a rapid diversification in many groups of biota, interrupted briefly by a most severe mass extinction at the end of the Period. True rugose corals appeared in the early Caradoc and as an emerging group contributed to both processes in a specific way. 
Corals colonized the Palaeobaltic Sea in the middle Caradoc. A century and a half of studies have produced many significant results related to their taxonomy and other aspects. A summary of the genus level taxonomic composition of the Baltoscandian rugose coral assemblages and some aspects of their diversity dynamics are presented by B. E. E. Neuman and D. Kaljo in Webby et al. (2004b).

Recent advances in Baltic isotope studies gave rise to the idea of using isotope data, together with biodiversity data, to investigate the role of environmental changes in the evolution and diversification of corals. The well-known diversity curves of Sepkoski (1995) show a generalized pattern of diversity change. Regional curves are more environmentally controlled and reveal details that can be correlated with stable isotope data, sea level curves, etc. These links are employed here for better understanding of the environmental background of certain bioevents. Conclusions are also based partly on the palaeoceanic and palaeoclimatic models suggested by Jeppsson (1990) and revised by Munnecke et al. (2003) for the Silurian Period.

Morphological novelties are the essence of coral evolution in leading to the appearance of new taxa. Usually, the time pattern of the latter process correlates somewhat with environmental changes and this allows biodiversity to be taken as a qualitative measure of possible ecological influence. Some useful pointers to this influence can be obtained via correlation of the coral diversity data with the late Ordovician carbon isotope trends.

\section{MATERIAL AND GEOLOGICAL-PALAEOGEOGRAPHICAL SETTING}

This paper is based on two sets of data: (1) Biodiversity data of rugose corals comprising the distribution of 30 genera and 91 species within time slices and local stratigraphic units (Neuman \& Kaljo in Webby et al. 2004b). In addition to corals collected in the outcrop areas, collections from a few drill cores (Farsund in particular; Smelror et al. 1997) and from various erratic blocks (e.g. Weyer 1983; Neuman 1986) were considered. Correlation of the coral occurrences and corresponding local rock units with standard stratigraphy and the establishment of unified time slices follow Webby et al. (2004b). Micropalaeontological datings are based on the chitinozoan biozonation (Nõlvak \& Grahn 1993). (2) Carbon isotope analyses of ca 500 whole-rock samples from 15 drill cores in Estonia and Latvia, plus a few tens of oxygen isotope analyses (Kaljo et al. 2001, 2004; Brenchley et al. 2003).

The late Ordovician East Baltic Gulf was part of a pericratonic sea on the western margins of the Baltica palaeocontinent, with an eastward epicratonic extension reaching Central Russia episodically. Coral-bearing carbonate rocks show cyclic alternation of different limestones, marlstones, and also reef-like structures at some levels, forming an outcrop belt of shallow water rocks in North Estonia and south of the St. Petersburg area (Männil \& Meidla 1994; Hints \& Meidla 1997). 
In Scandinavia, Ordovician corals occur in the corresponding rocks of the Oslo area (Asker, Ringerike) and in several separated outcrops in Sweden (Västergötland, Dalarna, Jämtland) (Neuman 1997; Webby et al. 2004b).

Local climate was influenced by the drift of the Baltica palaeocontinent from mid-latitudes to a subequatorial position during the Ordovician, as well as by global changes in the climate resulting in glacial conditions in the early Hirnantian (Brenchley et al. 2003). Recent summaries document general warming of the late Ordovician climate, evidenced by the first coral-stromatoporoid reefs and abundance of algal skeletal particles in the mid-Caradoc and younger limestones (Põlma 1972; Nestor \& Einasto 1997). The sedimentary record and carbon isotope excursions show repeated alternations of arid and humid climate in the late Ordovician, accompanied by several pre-Hirnantian cooling episodes (Kaljo et al. 2004).

For further discussion of relationships between changes in the environmental conditions, coral biodiversity, and carbon isotope trend some additional information about the sedimentary environment is necessary. Here the Estonian part of the Baltoscandian basin is taken as a basis for the interpretation of facies and climatic conditions. The Estonian sequence of local units is rather well correlated with those of the Oslo area and Sweden (Webby et al. 2004b), but some differences in facies interpretations (Nielsen \& Meidla 2004) still prevent basinwide generalizations of facies evolution.

The succession of facies changes during the part of the late Ordovician under study is described below. It is based on various geological data available (Hints \& Meidla 1997), the facies model currently in use, and the main pattern of basin evolution (Nestor \& Einasto 1997).

Middle Caradoc. The Haljala and Keila stages are represented mainly by highly argillaceous limestones and marlstones, with the most clayey varieties occurring in deeper shelf areas in South Estonia and Latvia. These rocks were formed during a sea level highstand, when the terrigenous influx into the basin was high. Only towards the end of Keila time and at the very beginning of Oandu time, the influx decreased and bioclastic limestones with bryozoan-microbial carbonate mounds and interreef cystoid grainstones became distributed, especially in NW Estonia. These facies changes were accompanied by local hiatuses in some areas, indicative of shallowing and regression of the sea. Ainsaar et al. (2004) termed them, together with a biotic crisis, the Middle Caradoc facies and faunal turnover. Here the turnover is interpreted as a change from the humid type of climate to a brief arid episode, which caused also changes in carbon cycling. In the second half of Oandu time the humid conditions were restored and highly argillaceous sediments were formed nearly all over the basin.

Late Caradoc. The Rakvere and Nabala stages are represented mainly by pure micritic limestones, widely distributed on the shelf. This indicates enhanced carbonate sedimentation in the conditions of arid climate and low terrigenous influx into the basin. A brief interval between these two arid episodes, corresponding to the lower part of the Nabala Stage, is represented by more argillaceous rocks argillaceous bioclastic limestones with intercalations of micritic limestones in the 
shallow shelf area. In the deeper sea belt, such intercalations are very rare. The lower Nabala limestones contain much less algal bioclasts than the under- and overlying micritic limestones (Põlma 1972). Nestor \& Einasto (1997) classify this interval as a humid episode.

The Vormsi Stage correlates with the Caradoc-Ashgill boundary beds and is one of the most argillaceous intervals in the Baltic Upper Ordovician (Männil \& Meidla 1994). A succession of lithofacies belts, represented by bioclastic limestones, and argillaceous limestones with glauconite and black shales, ranges from shallow to deep shelf (Hints \& Meidla 1997) and has been interpreted as a proxy of a distinct humid climate episode.

Ashgill. The Pirgu Stage comprises a complicated set of rocks differing in sequence as well as regionally. At least two cycles can be established (Hints \& Meidla 1997; Nestor \& Einasto 1997): (1) The lower Pirgu low influx interval, represented by micritic and bioclastic (often of algal origin) limestones with argillaceous intercalations, in some places also with carbonate mounds. This is a rather typical set for an arid climate episode. Higher follows a more humid sequence of various marls and argillaceous limestones. (2) More or less the same set of rocks and corresponding arid/humid conditions in the middle part of the Pirgu Stage and possibly also in the top of the stage. The third cycle is doubtful because of unclear relationships between different rock bodies and many gaps in sections.

The structure of the Porkuni Stage is also complicated by hiatuses, but for the purposes of this paper it is significant to note shallow shelf bioclastic limestones with stromatoporoid-tabulate bioherms and interreef beds of oolitic and kerogenous limestones. Sandy limestones occur in the top of the lower unit. More argillaceous limestones are distributed in deeper shelf environment and bioclastic limestones and marls overlain by silty and sandy limestones are present in the upper part of the stage, recognized only in South Estonia and Latvia (Hints \& Meidla 1997). The $\delta^{13} \mathrm{C}$ positive excursion, marking, according to Brenchley et al. (2003), the maximum level of the Hirnantian glaciation, was determined in North Estonia in the top of the Porkuni reef-bearing complex and in South Estonia in the middle of the stage, together with the occurrences of the Hirnantia brachiopod association (Kaljo et al. 2001).

\section{CARBON ISOTOPE BACKGROUND}

Carbon isotope studies (Kaljo et al. 1999, 2001, 2004) show cyclic changes in $\delta^{13} \mathrm{C}$ values through the Baltic late Ordovician. The following positive shifts (peak values shown in parentheses) have been identified:

- middle Caradoc shift (2.2\%o) at the transition from the Keila to Oandu stages;

- 1st late Caradoc shift (1.9\%o) in the lower part of the Rakvere Stage;

- 2nd late Caradoc shift (2.4\%o) in the upper part of the Nabala Stage;

- early Ashgill shift (2.5\%o) in the lowermost Pirgu Stage;

- middle Ashgill shift (2.0\%o) in the upper part of the Pirgu Stage;

- Hirnantian major peak $(6.7 \%$ o) in the Porkuni Stage. 
The magnitude of the $\delta^{13} \mathrm{C}$ shifts divides the late Ordovician into two different time intervals: the earlier long part $(\sim 10 \mathrm{Ma})$ of the epoch with minor $\delta^{13} \mathrm{C}$ variations $(2-2.5 \%)$, and a brief episode $(\sim 1.5 \mathrm{Ma})$ of intense $\delta^{13} \mathrm{C}$ changes $(4-7 \%$ ) at the end of the epoch. The former reflects the Caradoc and earlier Ashgill cooling episodes of lesser intensity (Kaljo et al. 2004), whilst the latter environmental changes are connected with the well-known Hirnantian glaciation event (Brenchley et al. 2003).

From the sedimentary environment of the shift intervals, described above under geological setting, it is clear that the peaks of most of the $\delta^{13} \mathrm{C}$ excursions, even if they begin during a humid episode, fall more or less exactly in arid intervals. This circumstance fits well with the oceanic model revised by Munnecke et al. (2003) but has some contradiction with Jeppsson's (1990) model predicting higher carbon isotope values in the cooler and more humid Primo episodes. However, the observations made here may not be detailed enough.

\section{BIODIVERSITY DYNAMICS}

\section{Evolutionary changes, timing of novelty events}

The oldest rugose corals of the Baltoscandian region (Primitophyllum, Lambelasma) appeared in the early middle Caradoc (time slice, further abbreviated t.s., 5b; for stratigraphy see Figs. 1,2). These were simple lambelasmatid corals with monacanthine septa and partly without tabulae. Later in the Caradoc (t.s. 5c) septa became longer and a calicular boss was formed (Coelostylis). Weak dissepiments appeared in the lambelasmatid skeleton (Neotryplasma) in the latest Caradoc (t.s. 5d) but became more developed in the Hirnantian (t.s. 6c).

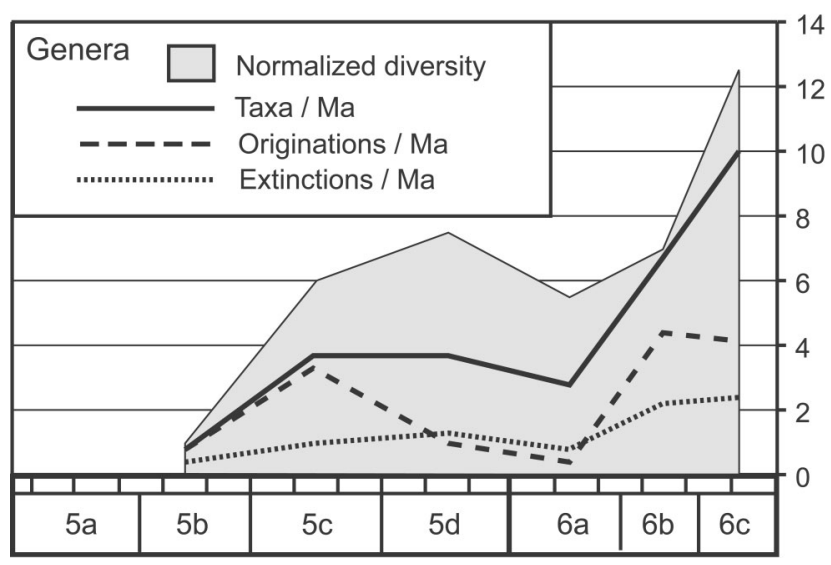

Fig. 1. Diversity dynamics of the Baltoscandian late Ordovician rugose coral genera (modified from Neuman \& Kaljo in Webby et al. 2004b). For correlation of time slices and local stratigraphy see Fig. 2. 


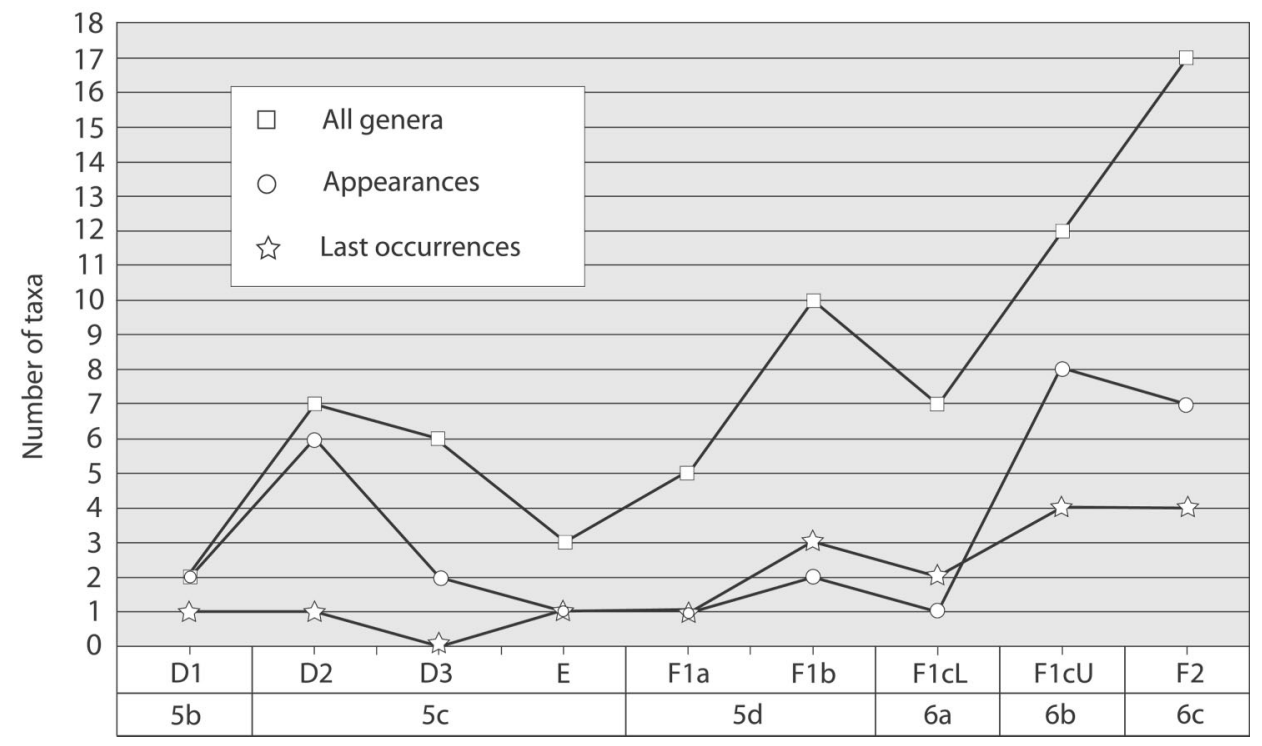

Fig. 2. Diversity dynamics of rugosan genera in the framework of Baltic late Ordovician stratigraphy. Indices of regional stages: D1, Haljala; D2, Keila; D3, Oandu; E, Rakvere; F1a, Nabala; F1b, Vormsi; F1cL, Lower Pirgu; F1cU, Upper Pirgu; F2, Porkuni.

The first streptelasmatids (Streptelasma, Helicelasma), which appeared in the late middle Caradoc (t.s. 5c), had an advanced septal apparatus and tabularium, but a complicated axial structure (Grewingkia, Bodophyllum) became common only in the early and middle Ashgill (t.s. 6a, b). Several morphological novelties such as septofossulae (Ullernelasma), dissepiments (Paliphyllum, Strombodes), and colonial forms (Cyathophylloides, Palaeophyllum), etc., appeared in the Hirnantian (t.s. 6c).

\section{Main biodiversity events}

The above discussion emphasizes the fact that the morphological advancement and taxonomic diversity of rugose corals increased steadily through the late Ordovician, yet with some set-backs in the numbers of taxa occurring at certain levels. For the analysis of diversity dynamics, the data on the distribution of rugose coral genera and species are summarized graphically (Figs. 1-3). Figure 1 is compiled according to the rules adopted in Webby et al. (2004a). Because of the rather long duration of several time slices (2.5-3 Ma) used in that publication, some details required for the present study are hidden, even though the general trends are adequately seen. Figures 2 and 3 show only numbers of taxa (genera and species) recorded in smaller regional units. These graphs allow better correlation with the carbon isotope curve. 


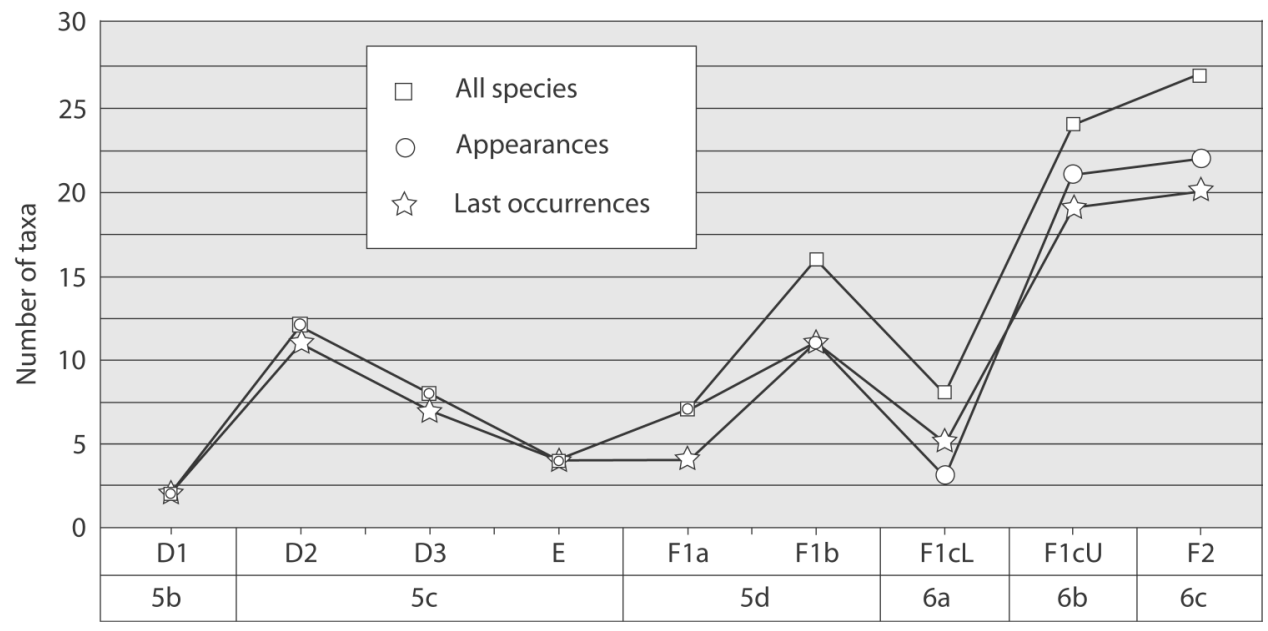

Fig. 3. Diversity dynamics of rugose coral species in the framework of the Baltic late Ordovician stratigraphy. For stage indices see Fig. 2.

Based on these data, the following main bioevents in the evolution of rugose corals in Baltoscandia can be identified.

1. The appearance of the oldest rugose corals in the earliest middle Caradoc.

2. The first diversity rise of rugose corals in the middle Caradoc caused by rapid radiation of lambelasmatids. The process was continued in the late Caradoc, supported by innovations among streptelasmatids.

3. The diversity low in the early Ashgill. This was not a sudden event but the decrease began already in the latest Caradoc.

4. The second notable diversification event that commenced in the middle Ashgill and peaked in the Hirnantian. This event was supported by the development of novelties in different groups of rugosans.

5. The end-Ordovician mass extinction is well expressed only at the species level. The generic diversity continued to increase and several genera survived, even if not observed in the earliest Silurian of Baltoscandia but recorded elsewhere (Kaljo \& Klaamann 1973).

\section{CORRELATION OF BIOEVENTS WITH THE CARBON ISOTOPE TREND}

The main data for correlation are summarized in Table 1, but consider also Figs. 1-3 and facies information given above under geological setting.

The correlation of coral diversity changes with the environmentally driven carbon isotope trends, suggested in Table 1, give no simple and unambiguous explanation of reasons for these changes. Somewhat remarkably, the coral 
Table 1. Coral diversity data and $\delta^{13} \mathrm{C}$ peak values plotted against time and climate

\begin{tabular}{|c|c|c|c|c|c|c|}
\hline M.y. & $\begin{array}{l}\text { Time } \\
\text { slice }\end{array}$ & $\begin{array}{l}\text { Regional } \\
\text { stage }\end{array}$ & Shift & $\begin{array}{l}{ }^{13} \mathrm{C} \text { peak } \\
\text { value, \%o }\end{array}$ & $\begin{array}{c}\text { Number of } \\
\text { genera, } \\
\text { total/appearing }\end{array}$ & $\begin{array}{l}\text { Climate } \\
\text { episodes }\end{array}$ \\
\hline \multicolumn{7}{|l|}{$443-$} \\
\hline $\begin{array}{l}444 \\
445-\end{array}$ & $6 c$ & Porkuni & Hirnantian & 6.7 & $17 / 7$ & $\begin{array}{l}\text { Humid } \\
\text { Arid/Humid }\end{array}$ \\
\hline $\begin{array}{l}446 \\
447-\end{array}$ & $6 b$ & Pirgu (upper) & mid-Ashgill & 2.0 & $12 / 8$ & $\begin{array}{l}\text { Humid } \\
\text { Arid }\end{array}$ \\
\hline $\begin{array}{l}448 \\
449\end{array}$ & $6 a$ & Pirgu (lower) & early Ashgill & 2.5 & $7 / 1$ & $\begin{array}{l}\text { Humid } \\
\text { Arid }\end{array}$ \\
\hline $\begin{array}{l}450 \\
451\end{array}$ & $5 d$ & $\begin{array}{l}\text { Vormsi } \\
\text { Nabala (upper) } \\
\text { Nabala (lower) }\end{array}$ & 2nd late Garadoc & 2.4 & $\begin{array}{r}10 / 2 \\
5 / 1\end{array}$ & $\begin{array}{l}\text { Humid } \\
\text { Arid } \\
\text { Humid }\end{array}$ \\
\hline 453 & $5 c$ & $\begin{array}{l}\text { Rakvere } \\
\text { Oandu }\end{array}$ & 1st late Caradoc & 1.9 & $\begin{array}{l}3 / 1 \\
6 / 2\end{array}$ & $\begin{array}{l}\text { Arid } \\
\text { Humid }\end{array}$ \\
\hline 454 & & $\begin{array}{l}\text { Keila (top) } \\
\text { Keila }\end{array}$ & mid-Caradoc & 2.2 & $7 / 6$ & $\begin{array}{l}\text { Arid } \\
\text { Humid }\end{array}$ \\
\hline $\begin{array}{l}455- \\
456\end{array}$ & $5 b$ & Haljala & & & $2 / 2$ & Humid \\
\hline
\end{tabular}

diversity peaks $(5 \mathrm{c}, \mathrm{d} ; 6 \mathrm{~b}, \mathrm{c})$ coincide in part with cooler or even glacial (early Porkuni/Hirnantian) climate episodes. A closer inspection clarifies some contradictions; e.g. time slice $5 \mathrm{c}$ (duration 3 m.y.) unites three local stages where generic diversity is (in ascending order) $7 / 6,6 / 2$, and 3/1. The mid-Caradoc $\delta^{13} \mathrm{C}$ shift occurs at the transition from the lower (Keila Stage) to the middle unit (Oandu Stage) and another one in the bottom of the upper unit (Rakvere Stage), clearly giving evidence of different environmental influence (Figs. 2 and 3). The first diversity rise took place during the humid episode but peaked when conditions became more arid. The event was marked by the mid-Caradoc shift. The diversity started to decrease during the following humid episode and, in spite of dominating arid climatic conditions marked by the 1st Late Caradoc shift, reached a minimum in Rakvere time.

The next clear coral diversity rise documented in Vormsi time coincides with the humid episode and low $\delta^{13} \mathrm{C}$ values. This rise, however, was not supported by enhanced innovation but only longer survival of coral genera. The same tendency continued also in the first half of Pirgu time under alternating humid and arid conditions. The innovation supported diversity rise began in the second half of Pirgu time (accompanied by the mid-Ashgill low $\delta^{13} \mathrm{C}$ peak) and continued during 
the first half of Porkuni time (coinciding with the early Hirnantian glacial and isotope events), while the background climate remained relatively changeable.

The above situation shows that general climate or temperature alone cannot explain all aspects of rugose coral diversity changes. Important factors seem to be also local or regional facies conditions, character of the sea bottom sediments (very fine muds are not preferred), and dynamics of the water in particular.

\section{BALTOSCANDIAN CORALS WITHIN THE GLOBAL ASSEMBLAGE OF RUGOSANS}

The role of Baltoscandian faunas in the global assemblage of rugose corals is analysed based on data from Webby et al. (2004b). It should be remembered that this work covers coral faunas of only three regions (Australasia, Baltoscandia, Laurentia) while several equally interesting faunas (China, Siberia, Central Asia, etc.; see Kaljo \& Klaamann 1973) are not dealt with. This means that the analysis is incomplete in a regional sense, but the basic data are largely modernized and therefore give a good general overview. In Webby et al. (2004b) Australasian rugosans are discussed by Webby, Laurentian material by Elias \& Young, and Baltoscandian material by Neuman \& Kaljo. In total, the distribution of 42 valid genera is documented. Thirty years ago Kaljo \& Klaamann (1973) analysed the distribution of only 29 genera, with 25 genera being represented in Baltoscandia, 13 in North America, 12 both in Siberia and Kazakhstan, 8 in China, and only a few in other areas. These data give some idea about the diversity of coral assemblages in the areas not dealt with in Webby et al. (2004b).

The relationships between the assemblages of the rugose coral genera from the three regions are shown in Fig. 4. It can be seen that (1) the Baltoscandian Ordovician rugose coral fauna is the most diverse, including 30 genera (in Laurentia 18, in Australasia only 10), and (2) the distribution of genera (number of genera restricted to one area, number of genera distributed in three areas, here referred to as "cosmopolitan", and the number of the genera common to two areas) differs greatly between the areas. The Baltoscandian assemblage is rather precisely defined but also has good ties with the Laurentian assemblage. Both have very few taxa in common with the Australasian assemblage, apart from the cosmopolitan genera. The cosmopolitan fraction has a relatively large share (40\%) in the last assemblage, which is twice to three times less in the more diverse assemblages of Baltoscandia and Laurentia. Restricted genera in Australasia also constitute $40 \%$, which means that the small fauna is at the same time a fairly original fauna. The Laurentian assemblage seems to be in these aspects the most "normal", or at least intermediate.

Two most striking aspects of the analysis shown in Fig. 4 require comment. Firstly, the high number of restricted genera occurring in Baltoscandia, for which there seem to be two obvious reasons: (a) corals have been studied in the region for more than a century and new studies are actively going on. And more importantly, 


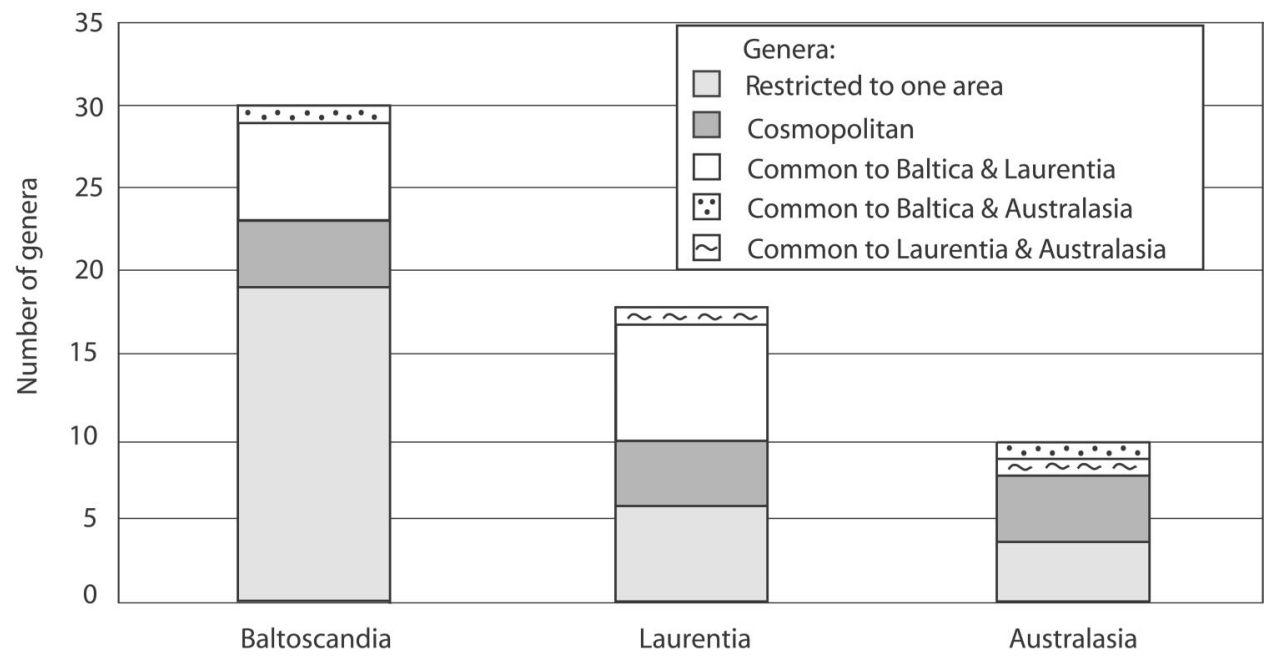

Fig. 4. Comparison of rugose coral assemblages in regions of three palaeocontinents.

(b) the oldest rugose corals (10 genera) in Baltoscandia belong to the family Lambelasmatidae - of which none has been found in Laurentia or Australasia. To say that none have been found might possibly be doubtful; although Elias \& Young (in Webby et al. 2004b) did not record any of these genera, it is known (Kaljo \& Klaamann 1973) that the genus Lambeophyllum Okulich has been described from Ordovician rocks in Canada. In analysing the available data, Weyer (1973) considered the genus to be doubtful in the region and suggested not to use the name before a new detailed study could be performed. The absence of lambelasmatids means that the Laurentian rugose coral assemblage is most likely younger (latest Caradoc or early Ashgill) than the first evolutionary burst of these primitive rugosans in Baltoscandia.

Secondly, in discussing the higher diversity of the rugose coral assemblage in Baltoscandia than in "equatorial" Laurentia, Webby et al. (2004b) noted that the most diverse rugose faunas, especially those dominated by solitary forms, were not necessarily restricted to low latitudes. This observation is surely true in the case of early solitary lambelasmatids with their habitats in slightly cooler and deeper waters of middle latitudes and during the mid-Caradoc sea level highstand. However, a much more essential diversification of the rugose assemblage took place in the middle and late Ashgill, when several novel morphologies and new genera appeared and continued into the Silurian. At that time the Baltica plate drifted into the subtropics and warm waters dominated on shallow shelves also during the Hirnantian glacial episode. It seems that the presence of such warm waters might serve as an explanation to the seeming discrepancy between coral diversity and cold climate. 


\section{CONCLUSIONS}

1. The first appearance of rugose corals in the shelf seas of Baltica in the Middle Caradoc seems to be linked with the warming of sea water and climate due to the drift of the continent closer to the equator. The same factor also favoured a further biodiversity rise in which both biology and ecology should be considered.

2. The general diversity rise was slowed down by repeated cooling in the late Caradoc and early Ashgill and caused together with other factors a diversity low in the early Ashgill.

3. Together with a favourable temperature regime, changes in oceanic circulation, nutrient flow, and availability of suitable habitats, character of bottom sediments in particular, were of great importance.

4. The Hirnantian glaciation, accompanied by a marked sea level fall, introduced favourable conditions for coral evolution on many subequatorial cratonic shelves, which helped corals to survive the severe conditions of the glacial period dominating at low latitudes.

5. The Baltoscandian rugose coral assemblage is the most diverse among those discussed because of the abundance of stratigraphically old lambelasmatids living in relatively cooler and deeper habitats.

\section{ACKNOWLEDGEMENTS}

Some aspects of the paper were discussed at the 32nd International Geological Congress, Florence (session G 17.03, 21 August 2004). The paper benefited greatly from constructive reviews by M. G. Bassett and H. Nestor. The author thanks his colleagues for useful comments and G. Baranov for technical help. The study was partly supported by the Estonian Science Foundation (grant No. 5042).

\section{REFERENCES}

Ainsaar, L., Meidla, T. \& Martma, T. 2004. The Middle Caradoc facies and faunal turnover in the Late Ordovician Baltoscandian palaeobasin. Palaeogeogr. Palaeoclimatol. Palaeoecol., 210, 119-133.

Brenchley, P. J., Carden, G. A., Hints, L., Kaljo, D., Marshall, J. D., Martma, T., Meidla, T. \& Nõlvak, J. 2003. High resolution isotope stratigraphy of Late Ordovician sequences: constraints on the timing of bio-events and environmental changes associated with mass extinction and glaciation. Geol. Soc. Amer. Bull., 115, 89-104.

Hints, L. \& Meidla, T. 1997. Viru Series (Middle Ordovician), Harju Series (Upper Ordovician). In Geology and Mineral Resources of Estonia (Raukas, A. \& Teedumäe, A., eds.), pp. 64-88. Estonian Academy Publishers, Tallinn. 
Jeppsson, L. 1990. An oceanic model for lithological and faunal changes tested on the Silurian record. J. Geol. Soc. London, 147, 663-674.

Kaljo, D., Hints, L., Hints, O., Martma, T. \& Nõlvak, J. 1999. Carbon isotope excursions and coeval biotic-environmental changes in the late Caradoc and Ashgill of Estonia. In Quo vadis Ordovician? (Kraft, P. \& Fatka, O., eds.), Acta Univ. Carolinae Geol., 43, 507-510.

Kaljo, D., Hints, L., Martma, T. \& Nõlvak, J. 2001. Carbon isotope stratigraphy in the latest Ordovician of Estonia. Chem. Geol., 175, 49-59.

Kaljo, D., Hints, L., Martma, T., Nõlvak, J. \& Oraspõld, A. 2004. Late Ordovician carbon isotope trend in Estonia, its significance in stratigraphy and environmental analysis. Palaeogeogr. Palaeoclimatol. Palaeoecol., 210, 165-185.

Kaljo, D. \& Klaamann, E. 1973. Ordovician and Silurian corals. In Atlas of Palaeobiogeography (Hallam, A., ed.), pp. 37-45. Elsevier, Amsterdam.

Männil, R. \& Meidla, T. 1994. The Ordovician System of the East European Platform (Estonia, Latvia, Lithuania, Byelorussia, parts of Russia, Ukraine, Moldavia). Intern. Union Geol. Sci. Publ., 28, 1-52.

Munnecke, A., Samtleben, C. \& Bickert, T. 2003. The Ireviken Event in the lower Silurian of Gotland, Sweden - relation to similar Palaeozoic and Proterozoic events. Palaeogeogr. Palaeoclimatol. Palaeoecol., 195, 99-124.

Nestor, H. \& Einasto, R. 1997. Ordovician and Silurian carbonate sedimentation basin. In Geology and Mineral Resources of Estonia (Raukas, A. \& Teedumäe, A., eds.), pp. 192-204. Estonian Academy Publishers, Tallinn.

Neuman, B. E. E. 1986. Rugose corals from the Upper Ordovician erratic boulders of Öland. Geol. Fören. Stockholm Förh., 108, 349-365.

Neuman, B. E. E. 1997. Evaluation of rugose coral potentials as index fossils. Bol. Real Soc. Esp. Hist. Nat. (Geol.), 92, 303-309.

Nielsen, A. \& Meidla, T. 2004. Late Ordovician sea level changes in the Oslo area and Estonia: tiepoints and problems. In WOGOGOB-2004 Conference Materials (Hints, O. \& Ainsaar, L., eds.), pp. 73-74. Tartu University Press, Tartu.

Nõlvak, J. \& Grahn, Y. 1993. Ordovician chitinozoan zones from Baltoscandia. Rev. Palaeobot. Palynol., 79, 245-269.

Põlma, L. 1972. Skeletal debris content and composition in the sediments of the northern facial belt of the East Baltic Ordovician (Rapla boring). Eesti NSV TA Toim. Keemia, Geol., 21, 326-332 (in Russian).

Sepkoski, J. J. 1995. The Ordovician radiations: diversification and extinction shown by global genus-level taxonomic data. In Ordovician Odyssey: Short Papers for the 7th International Symposium on the Ordovician System (Cooper, J. D., Droser, M. L. \& Finney, S. C., eds.), pp. 393-396. Pacific Section, Society for Sedimentary Geology, Fullerton, California.

Smelror, M., Cocks, L. R. M., Mørk, A., Neuman, B. E. E. \& Nakrem, H. A. 1997. Upper OrdovicianLower Silurian strata and biota from offshore South Norway. Norsk Geol. Tidskr., 77, 251-268.

Webby, B. D., Droser, M. L., Paris, F. \& Percival, I. G. (eds.). 2004a. The Great Ordovician Biodiversification Event. Columbia University Press, New York.

Webby, B. D., Elias, R. J., Young, G. A., Neuman, B. E. E. \& Kaljo, D. 2004b. Corals. In The Great Ordovician Biodiversification Event (Webby, B. D., Droser, M. L., Paris, F. \& Percival, I. G., eds.), pp. 124-146. Columbia University Press, New York.

Weyer, D. 1973. Über den Ursprung der Calostylidae Zittel 1879 (Anthozoa Rugosa, OrdovizSilur). Freiberger Forschungshefte, C 282, 23-87.

Weyer, D. 1983. Lambelasma-Arten (Anthozoa, Rugosa) aus dem baltoskandischen Mittelordoviz. Freiberger Forschungshefte, Leipzig, C 384, 7-19. 


\title{
Baltoskandia Hilisordoviitsiumi rugooside mitmekesisus: keskkonnamuutuste roll ja võrdlus teiste aladega
}

\begin{abstract}
Dimitri Kaljo
Regionaalsed bioloogilist mitmekesisust kajastavad kõverad on teatud määral kooskõlas keskkonnatingimuste muutuste käiguga ja see võimaldab neid rööbistada stabiilsete isotoopide, meretaseme jm muutuste graafikutega. Seda asjaolu on kasutatud käesolevas töös käsitletud biosündmuste põhjuste selgitamisel. Esimesed rugoosid ehk tetrakorallid ilmusid Baltica mandri ääremeredesse Hilisordoviitsiumi Kesk-Caradoci ajajärgul, mil nimetatud paleokontinent hakkas lähenema ekvaatorile ja kliima muutus korallide eluks piisavalt soojaks. Rugooside taksonoomilise mitmekesisuse esimene tipp langeb Keila ea lõppu, mil oli valdavaks lühiajaline ariidse kliima episood, järgnevad Hilis-Caradoc ja Vara-Ashgill olid vahelduva kliimaga ja enamasti peeneteralise lubimuda väga ulatusliku settimise aeg. Need tingimused põhjustasid rugooside mitmekesisuse vähenemise. Uus mitmekesisuse kasv algas Kesk-Ashgilli Pirgu ea teisel poolel ja jätkus ka Porkuni eal, nn Hirnantia jäätumise ajal. Saadud andmed näitavad, et temperatuuri kõrval on rugooside eluks olulised ka merepõhja iseloom ja vee liikuvus. Laurentia ja Australasia tetrakorallide kooslustega võrreldes on Baltica merede korallifauna palju rikkalikum eeskätt vanima sugukonna Lambelasmatidae rohke esinemise tõttu. Need primitiivsed korallid elasid tavalisest pisut sügavamas ja jahedamas vees.
\end{abstract}

